\title{
Quaternary Coastal Landscape Evolution and Sea-Level Rise: An Example from South-East Sicily
}

\author{
Salvatore Distefano $^{1, *}$, Fabiano Gamberi ${ }^{2}$, Laura Borzì ${ }^{1}$ iD and Agata Di Stefano ${ }^{1}$ \\ 1 Dipartimento di Scienze Biologiche, Geologiche ed Ambientali, Università degli Studi di Catania, \\ Corso Italia 57, 95129 Catania, Italy; laura.borzi@unict.it (L.B.); agata.distefano@unict.it (A.D.S.) \\ 2 Istituto di Scienze Marine Consiglio Nazionale delle Ricerche, Via Gobetti 101, 40129 Bologna, Italy; \\ fabiano.gamberi@bo.ismar.cnr.it \\ * Correspondence: salvatore.distefano@unict.it; Tel.: +39-09-5719-5724
}

check for

updates

Citation: Distefano, S.; Gamberi, F.; Borzì, L.; Di Stefano, A. Quaternary Coastal Landscape Evolution and Sea-Level Rise: An Example from South-East Sicily. Geosciences 2021, 11, 506. https://doi.org/10.3390/ geosciences 11120506

Academic Editors: Luigi Bruno,

Bruno Campo and

Jesus Martinez-Frias

Received: 19 October 2021

Accepted: 7 December 2021

Published: 10 December 2021

Publisher's Note: MDPI stays neutral with regard to jurisdictional claims in published maps and institutional affiliations.

Copyright: (C) 2021 by the authors Licensee MDPI, Basel, Switzerland. This article is an open access article distributed under the terms and conditions of the Creative Commons Attribution (CC BY) license (https:/ / creativecommons.org/licenses/by/ $4.0 /)$.

\begin{abstract}
Coastal depositional environments are the site of complex interactions between continental and marine processes. Barrier islands are highly dynamic coastal systems, typical of these transitional environments, and are affected by sea level changes and the accumulation of transgressive deposits with the landwards migration of the coast. The offshore of Marzamemi (Syracuse Province, Sicily), in the south-eastern portion of the Hyblean foreland, represents an excellent site for the study of transgressive deposits and their connection with the sea-level changes. The available dataset consisted of new high-resolution bathymetry (Multibeam), whose description and interpretation through a Digital Elevation Model (DEM) was integrated with a grid of eighteen seismic profiles (SPARKER). In the investigated bathymetric range, from about $-5 \mathrm{~m}$ to $-60 \mathrm{~m}$, a sensibly different morphological setting between the northern and southern sectors was evident. Within the whole study area, three bathymetric contours $(-45 \mathrm{~m},-35 \mathrm{~m}$ and $-20 \mathrm{~m})$ were identified and assumed as the markers of the main locations of the paleo-coastlines during the recent changes in the sea level. Along the northern sector, three submerged barrier-lagoon systems developed on a calcarenite substratum, marking important steps of the Late Quaternary sea-level rise. They coexisted with numerous karst forms (poljes and dolines). In the southern sector the transgressive environmental evolution was significantly different and submerged lagoons did not form. Here the outcropping calcarenite substratum was affected by the development of paleo-rivers and karsts structures, a tract in common along with many Mediterranean carbonate coastal areas.
\end{abstract}

Keywords: morphological evolution; barrier-lagoon system; multibeam data

\section{Introduction}

Late Quaternary clastic transgressive coasts often consist of typical barrier-lagoon systems that migrate landwards as the sea level rises [1-4]. This type of transgression [5] is generally accepted as the dominant type of coastline retreat and may be considered a significant record of high-frequency and high-amplitude sea-level changes due to glacioeustasy [6].

Progressive or irregular landward shifts of facies are signs of transgressive deposits formed over short time scales, and the landward coastline migration often occurs with: (i) an increase in sedimentation within the alluvial and coastal plain, (ii) a decrease in the sediment influx to the basin, and (iii) the ravinement of ancient deposits, even those accumulated during the early stages of the transgression event [6]. Research on ancient and recent transgressive successions is a key issue since their investigation can provide information on the eustatic sea-level behavior. The oceanographic or paleoceanographic data are used to identify the depositional processes and relationships to the current physiography [6].

Coastal plains represent the place where numerous interactions between continental and marine processes occur and, in particular, the barrier islands represent peculiar highly 
dynamic coastal systems that are characteristic of these transitional environments. Barrier islands are low-lying features that are highly affected by sea-level changes and variations in the coastal sediment budget [7]. These coastal features can isolate lagoon bodies and are mainly influenced by the action of waves and by tides, winds, currents, and river processes, which transport, deposit, and rework sediments along the coastline [8,9]. In response to local coastal changes, and due to the combination of transgressive and regressive cycles, a barrier island can behave in different ways, for example moving landward across the underlying substrate to higher elevations [10]. The physical features of the coast and the sedimentary supply directly influence the structuring of barrier islands, and their preservation within the rock record depends upon the amount of erosion that occurs during the subsequent transgression. However, barrier elements are those that better preserve the coastal deposits [11].

Coastal carbonate formations are often stable systems that experience relatively high geomorphic inertia; thus, they are well-suited to record the geomorphological features of past sea level oscillations and stillstands, allowing the reconstruction of major paleogeographic events [12]. Indeed, karst landforms produced by the subaerial dissolution of carbonate rocks are found worldwide where carbonate formations are widespread, and at places deeply impact on the landscape [13-17]. Relationships between present morphostructural settings and the distribution of different types of surficial and subsurface karst forms show the importance of lithology, climate, and exposure time in controlling the intensity of morphologic and karst processes [12].

The availability of new bathymetric data in the offshore area of Marzamemi (SR, Sicily), in the south-eastern portion of the Hyblean foreland, represents an opportunity to reconstruct the depositional history of the transgressive deposits and their relationship with the sea level rise. The coastal plain is mainly made up of calcarenite formations (Marzamemi Formation) and, therefore, a place where karst forms can easily develop. In fact, the carbonate formations, under the action of eustatic and/or tectonic forcing during the Pliocene and the Quaternary, and the consequent repeated changes in the karst base level, led to complex multiphase karst [12], largely outcropping also along the current coast of Marzamemi also. From a geomorphological point of view, the study area is part of the Pantani area of the Vendicari Natural Reserve (Syracuse), a coastal stretch characterized by a series of lagoons parallel to the actual coastline, separated by the open sea by elevated ridges of Tyrrhenian calcarenites and by coastal sand barriers [18]. Here, the sub-horizontal attitude of the carbonate series surely allowed the development of a polje: a wide, shallow depression. Poljes are karst depressions whose genesis is related to the corrosional lowering of the land surface, commonly beneath a loose, permeable, and non-karst, usually alluvial or soil, cover. Most of the poljes were likely subaerial depressions, but in the present-day they can be found in the sublittoral zone having been submerged following the last sea level rise [19-22].

High-resolution seismic data are powerful tools to map key surfaces of on- and offshore coastal deposits; nevertheless, there are, so far, relatively few studies in coastalplain areas that actually represent good analogues for many ancient basins [6].

From a stratigraphic point of view, the area has recently been described and interpreted by the authors of [23], who focused on the relationship between the Quaternary transgressive deposition and sea-level variations through the interpretation of eighteen (18) sub-bottom Sparker profiles. In this work, we expand on this analysis with particular focus on the reconstruction of the morphological evolution of the area. We take advantage of the further support of a new high resolution bathymetric dataset (DEM), which represents a very useful integration for the interpretation of submerged transgressive geomorphic elements (Figure 1). 


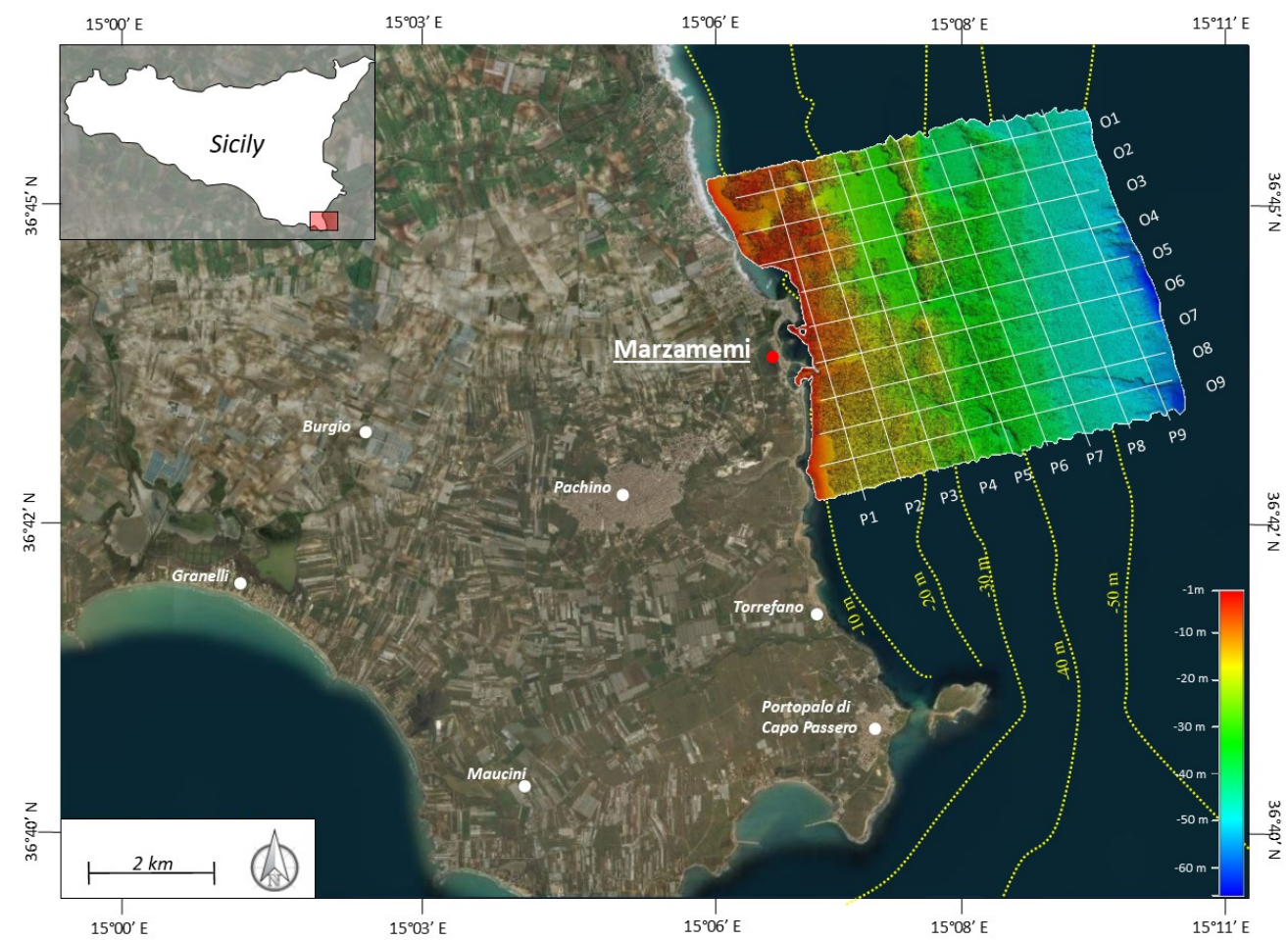

Figure 1. Geographic map (WGS 84) of south-eastern Sicily and the offshore sector investigated in the present study (Marzamemi area) through a bathymetric survey carried out with a RESON Seabat 8125 Multibeam sonar. The bathymetric contours every $10 \mathrm{~m}$ are shown in yellow; the traces of the seismic profiles are shown in white.

\section{Study Area}

The offshore of Marzamemi is part of the southeastern area of the Hyblaean Plateau (Figure 2), which is the emerged sector of the NE-SW-oriented continental bulge of the African foreland, consisting of the Mesozoic-Cenozoic carbonate sedimentary successions (Pelagian Block) [24-26]. The Hyblaean foreland is bounded to the northwest by the Caltanissetta Basin, an asymmetric trough, wedged between the foreland and the belt. To the east, the plateau is delimited by the Malta Escarpment that separates the Pelagian shelf from the Ionian abyssal plain [27]. The Gela-Catania foredeep, a Plio-Pleistocene basin, flanks the Hyblean foreland and extends to the southern and southwestern part of Sicily offshore [28-31]. Since the Cretaceous, the Tellaro River valley separated the Hyblean Plateau into two tectonic domains, (i) the eastern or Siracusa domain and (ii) and the western or Ragusa domain [32-35].

The Marzamemi offshore coastal plain is part of the Syracuse domain, with some features more pertinent to a transitional domain [23], because here the geomorphic elements that highlight the transition between continental and marine environments are numerous. The stratigraphic succession starts with Upper Cretaceous massive limestones with Rudist remnants (Priolo Fm. Auct.) associated with the products of subaerial volcanic events. The overlying sedimentary succession [36-40] is represented by white-pinkish Nummulitic calcirudites of the Paleocene-Eocene age and the blue-gray marls of the Tellaro Formation of the middle to late Miocene age.

The Pliocene units consist of the Zancleano Trubi Fm. [41-44], and white-yellowish marls of Piacenzian age. Polygenic conglomerates of probable Pliocene age outcrop west and south-west of the Pachino village [37]. The Quaternary strata crop out within the studied coastal area and are made up of Tyrrhenian reddish organogen calcarenites, known as the Marzamemi Formation [38], of Holocene alluvial and lagoonal sediments, and of the present-day beach deposits [36-40]. 


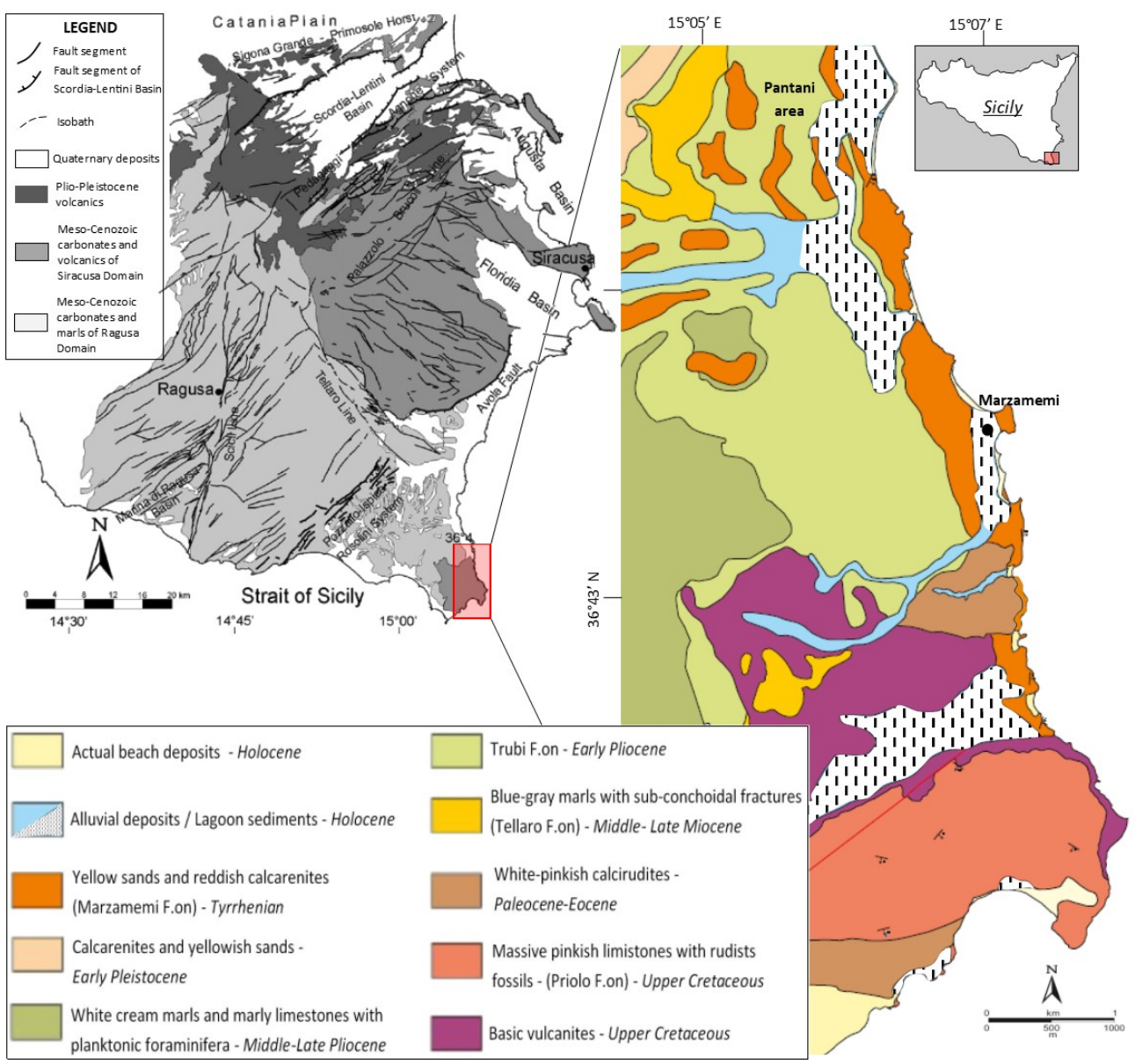

Figure 2. Schematic geological and structural map (WGS 84) of the Hyblean region (modified from [26]). The inset in red represents the location of Marzamemi (Syracuse, Sicily) with detail of the geological structure of the area (modified from [23]).

The present-day geomorphological setting of the Marzamemi coastal area was probably last shaped by Late Pleistocene tectonic events. In particular, a NNW-SSE structural trend has controlled and affected the orientation of the Marzamemi rocky coast. Some authors [44] claim that the general outline of the Vendicari submerged poljes is connected with the activity of fractures parallel to the Malta fault, which caused a gentle tectonic NNW-SSE-trending depression and a slight uplift of its surroundings.

\section{Materials and Methods}

The Digital Elevation Model (DEM) used in the interpretation of the morphological framework of the Marzamemi proximal offshore was obtained through a bathymetric survey carried out with a RESON Seabat 8125 Multibeam sonar (MBES; Figure 3).

Before starting the acquisition operations, an on-board bar-check and a calibration of the settings of the gain and TVG (Time Varied Gain) values were performed in order to obtain a reliable and low-noise dataset. Both during the calibration and the surveys, sound velocity profiling of the water column was performed using the SVP (Sound Velocity Probe). The acquisition of bathymetric data was carried out following a navigation plan with parallel lines and a line spacing of $25 \mathrm{~m}$. The overlap between adjacent lines was never less than 25\%. The MBES dataset was integrated with the seismic Sparker lines (Geo-Spark 1000 Pulsed Power Supply system) amounting at about $100 \mathrm{~km}$ of lines, forming a grid of eighteen profiles. 


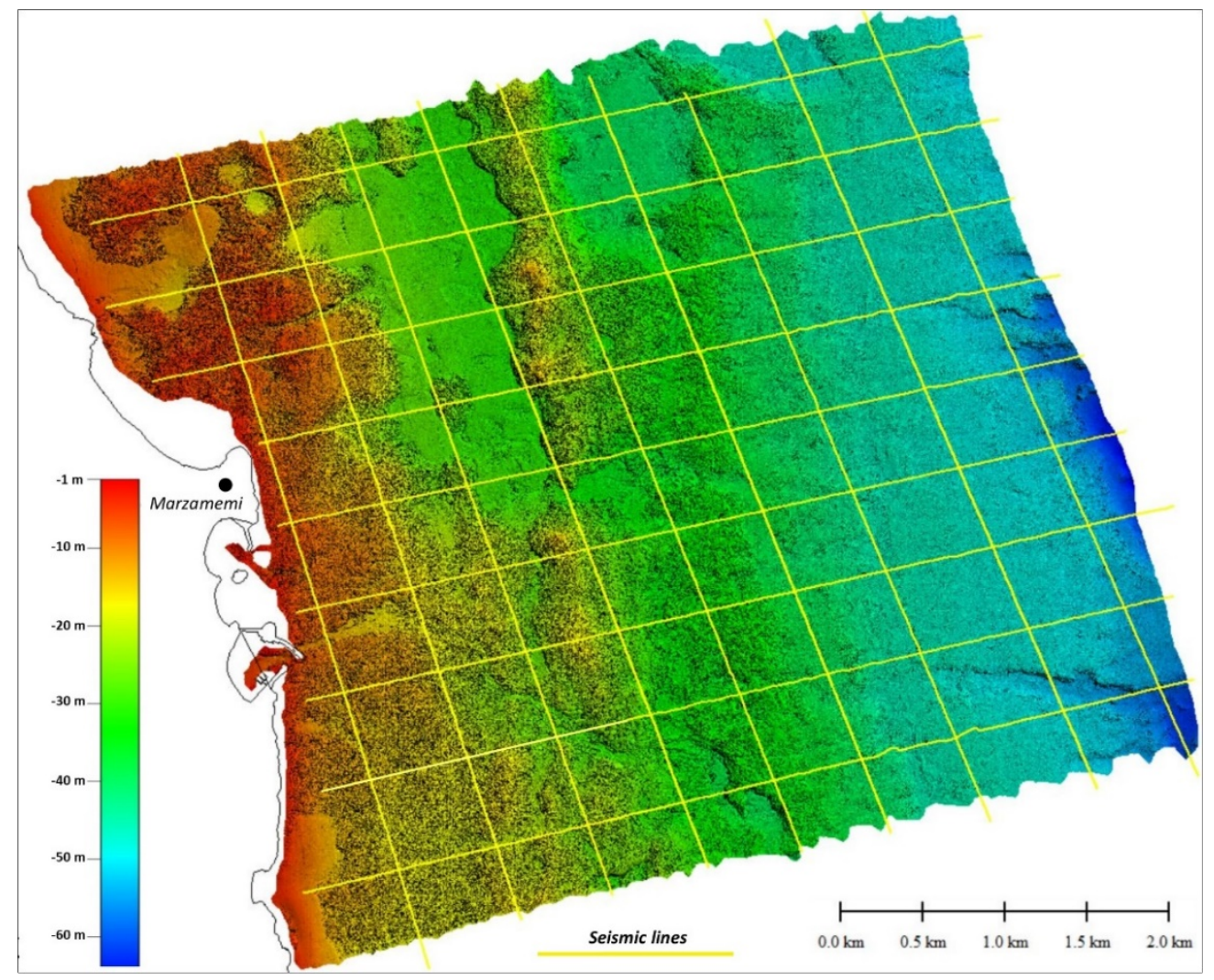

Figure 3. Overlapping of the datasets analyzed for the geomorphological reconstruction of the Marzamemi offshore: the bathymetric data (Multibeam) and the grid of seismic profiles (Sparker).

The seismic profiles, acquired in SEG-Y format, were processed and interpreted using the Geo-Suite software (2020R2 version). Initially, a standard processing sequence-already applied to similar data in the Mediterranean area [45] — was used for all seismic profiles. The seismic profiles (penetrating about $150 \mathrm{~ms}$ TWT) had a high resolution $(<1 \mathrm{~m})$, allowing the identification of the upper part of the sedimentary succession. The recorded seismic profiles show lights on a crustal portion whose thickness ranged from a minimum of $5 \mathrm{~m}$, in proximity to the coastline, to a maximum of $120 \mathrm{~m}$ seaward.

\section{Results}

The Marzamemi (SR) offshore represents an excellent site for the study of the sedimentary expression of the last transgressive and highstand of the last sea-level cycle, in part of the Ionian Sea.

Through the comparative study of the bathymetric (MBES) and seismic-stratigraphic data (Sparker system), we present a detailed description and interpretation of the morphological features of the seabed, in order to show the depositional evolution during the recent variations in the sea level.

Four acoustic reflectivity classes were identified within the Multibeam map dataset (Figure 4). The comparison with similar studies also showing the photogrammetric data of the Mediterranean area [46], was used to assign to the four classes of acoustic response lithological, grain size, and biological attributes. In particular (Figure 4), the first classcharacterized by low reflectivity and a homogenous seafloor-is correlated with fine sediments (I class). The second class is characterized by medium reflectivity and a homogeneous seafloor with patches and small rugosity and is correlated with coarse sediments (II class). The third class is characterized by high reflectivity and a high rugosity and is correlated with the calcarenite substratum (III class). The fourth class is characterized by the alternation between high and low reflectivity and smooth patches within high rugosity areas and is correlated with Posidonia Oceanica meadows (IV class). 


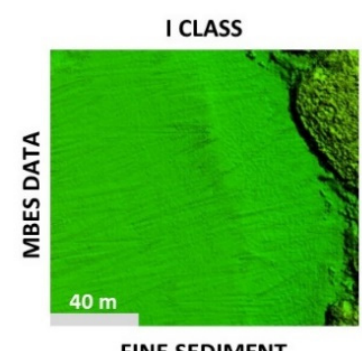

FINE SEDIMENT

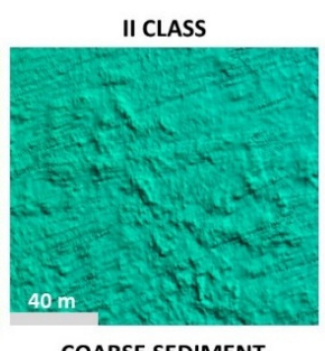

COARSE SEDIMENT

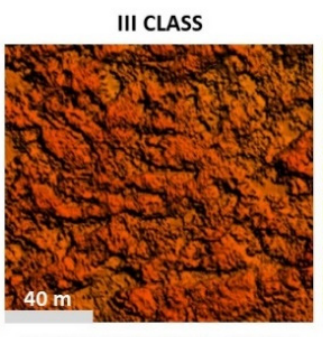

CALCARENITE SUBSTRATUM

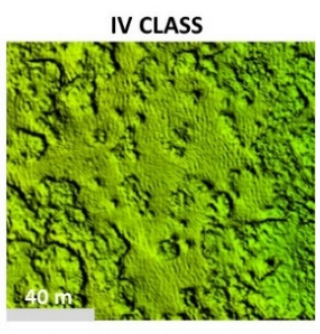

POSIDONIA OCEANICA

Figure 4. Correlation between the Multibeam data (MBES) and the more representative lithological, grain size, and biological attributes recognized in the study area.

The investigated bathymetric range was from about $-5 \mathrm{~m}$ to $-60 \mathrm{~m}$ and shows (Figure 5) markedly different morphological settings in the northern and southern sectors. Within the whole study area, three bathymetric contours $(-45 \mathrm{~m},-35 \mathrm{~m}$ and $-20 \mathrm{~m}$; Figure 5) were chosen as the markers of the locations of the key paleo-coastlines during the post-glacial sea level rise. Of course, during the transgression, the coastlines moved gradually landwards, but not all coastlines have been preserved as geomorphic elements in the present-day seafloor. This reflects the seafloor erosion that occurred during the early transgressive submergence of the majority of the coastlines. However, some past coastal geomorphological features are still completely preserved and were well-imaged in our Multibeam data. Of these, the best imaged correspond to the $-45,-35$ and $-20 \mathrm{~m}$ contours, and were used for our paleo-environmental analysis of the study area.

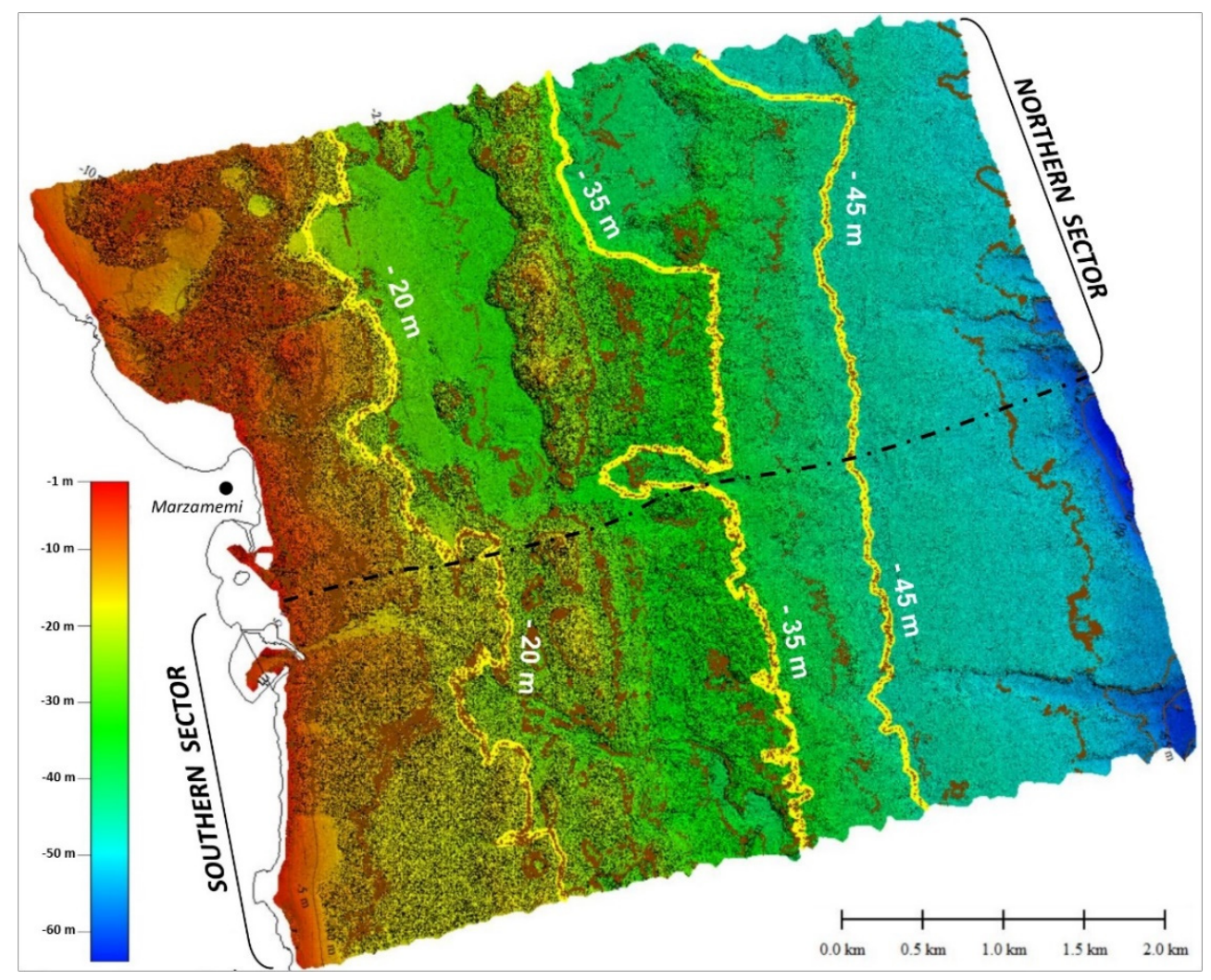

Figure 5. Multibeam dataset. The black dashed line divides the southern sector from the northern one. The yellow lines represent the 3 contours assumed to be the markers of the locations of the key paleo-coastlines.

In particular, the $-45 \mathrm{~m}$ contour shows a general, relatively regular trend from north to south. Only in the northernmost portion is the presence of a cuspate paleo-coastline with 
an extension of about $1.5 \mathrm{~km}$ revealed. On the contrary, the $-35 \mathrm{~m}$ and $-20 \mathrm{~m}$ contours show a more jagged and irregular trend.

The following description uses these key contours as references to highlight the different morpho-structures recognized in the northern and southern sectors.

\subsection{Northern Sector}

The northern sector extends for about $13 \mathrm{~km}^{2}$ and is characterized by the presence of a marked variability in the sedimentary morpho-structures, which are repeated from east to west. The map in Figure 6 shows the different acoustic features of the sector. The profile $\mathrm{A}-\mathrm{A}^{\prime}$ shows the stepped arrangement of three main depressions, whose extension increases westward as the depth decreases (Figure 6).

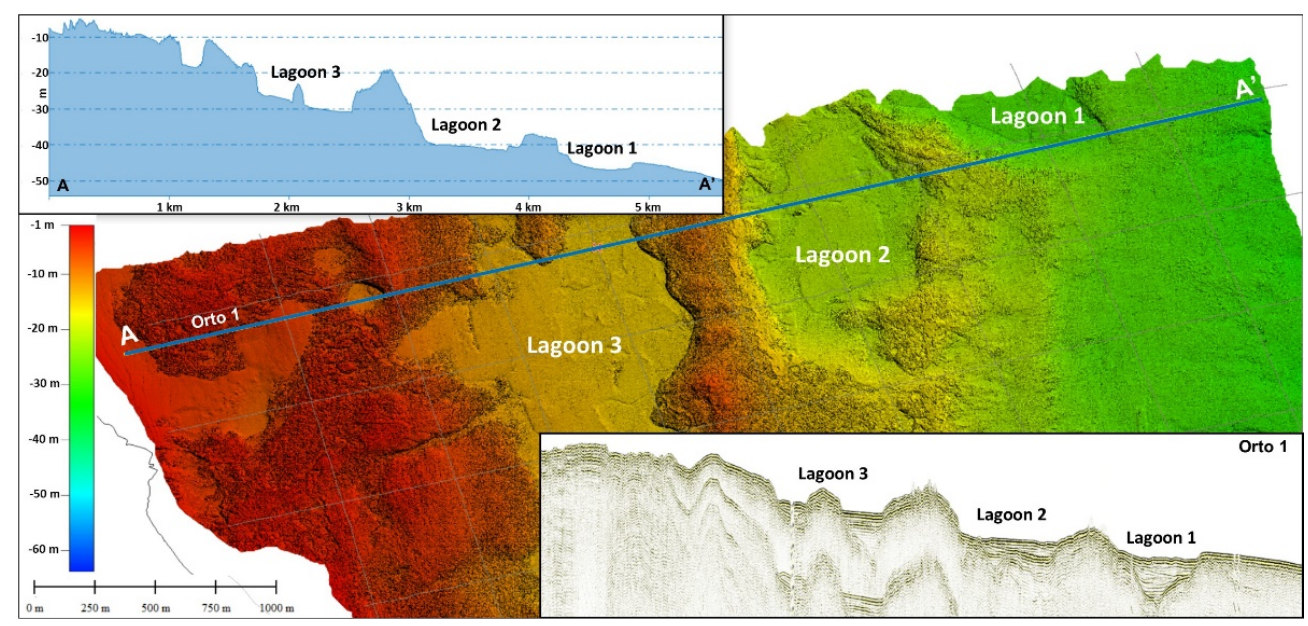

Figure 6. Location of Lagoon 1, Lagoon 2, and Lagoon 3 within the northern sector of the study area and the comparison between the bathymetric and seismic profiles (Orto 1).

The $-45 \mathrm{~m}$ contour bounds the first of these depressions, which covers an area of about $0.3 \mathrm{~km}^{2}$, although it probably extends further to the north, outside the study area. This depression is interpreted as a submerged lagoon and is here named Lagoon 1 (L1). The trend of the $-45 \mathrm{~m}$ contour marks the morphological development of L1, which is sub-circular and only slightly elongated in a south-east direction (Figure 7). To the west and to the south, L1 is confined by a flat morphology (dipping at about $1^{\circ}$ ) interpreted as a paleo-beach (Figure 7, profile B- $\mathrm{B}^{\prime}$ ); conversely, to the east a high and steep escarpment is can be interpreted as a paleo-cliff (Figure 7, profile $C-C^{\prime}$ ). These morphological features correspond to variations in the penetration of the acoustic signal in the seismic profile of Orto 1 (Figure 7). A high penetration corresponds with the beach deposits, probably characterized by relatively fine-grained deposits. A low penetration characterizes the area to the east of L1, corresponding to the paleo-cliff, where a hard substratum with most likely carbonate lithology outcrops.

In the central portion of L1 (Figure 8) numerous morphological irregularities consisting of elongate depressions highlight a system of bars and channels, with differential relief between $50 \mathrm{~cm}$ and $1 \mathrm{~m}$ (Figure 8, profiles $\mathrm{D}^{-\mathrm{D}^{\prime}}$ and $\mathrm{E}-\mathrm{E}^{\prime}$ ). Their origin could be connected with the action of intra-lagoon tidal currents. These bars and tidal channels are also clearly visible in the seismic profile of Orto 1 (Figure 8).

To the south-east, L1 shows a narrow opening (about $50 \mathrm{~m}$ ) which probably represented the paleo-connection with the open sea (Figure 8) located in the easternmost portions of the study area. Here, the acoustic character of the MBES dataset becomes diffusely more homogeneous, degrading weakly up to a depth of about $-60 \mathrm{~m}$.

L3 shows a flat seafloor that is interrupted by the high escarpment to the east. Here, the sediments are probably fine grained, in agreement with the penetration of the acoustic signal (Figure 11, I-I' and J-J' profiles). 


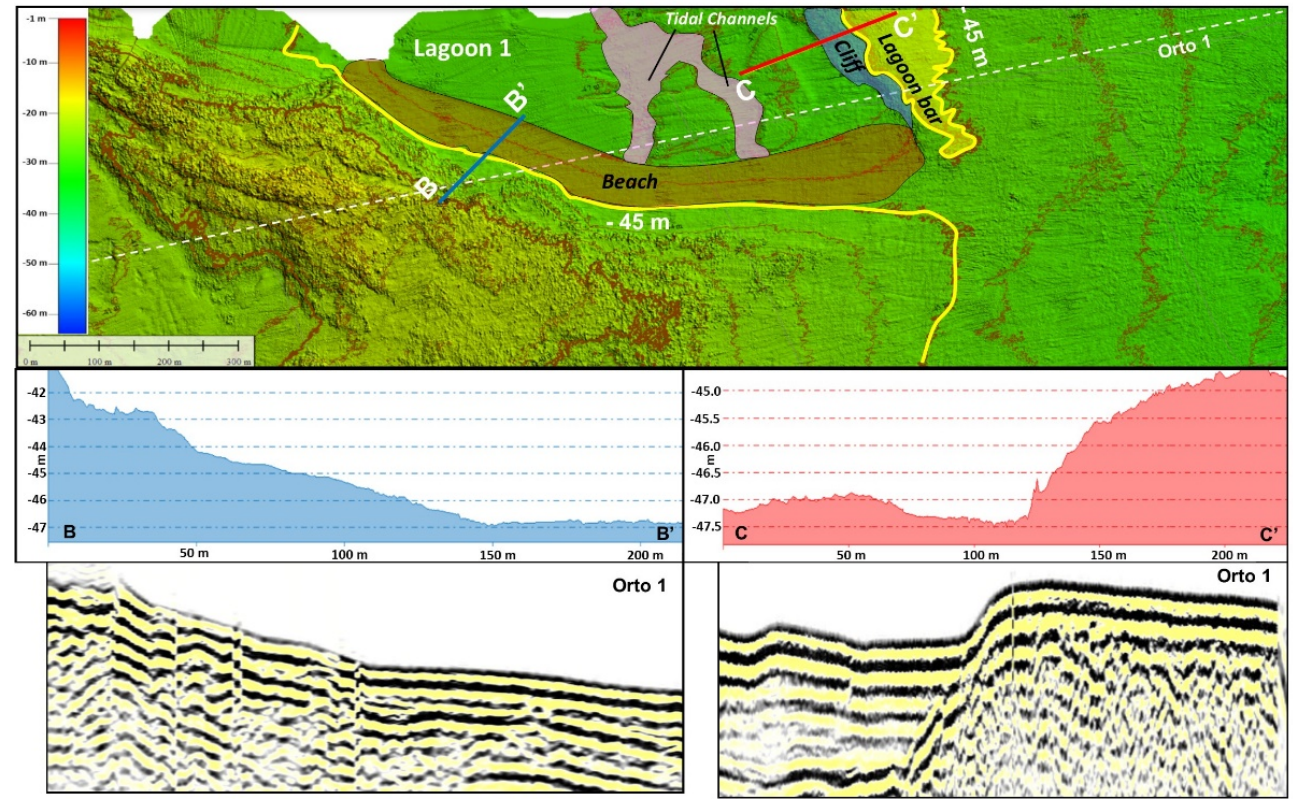

Figure 7. Location of Lagoon 1 within the northern sector of the study area and the comparison between the bathymetric profiles to the west $\left(B-B^{\prime}\right)$ and to the east $\left(C-C^{\prime}\right)$ of $L 1$ and the seismic profile (Orto 1).

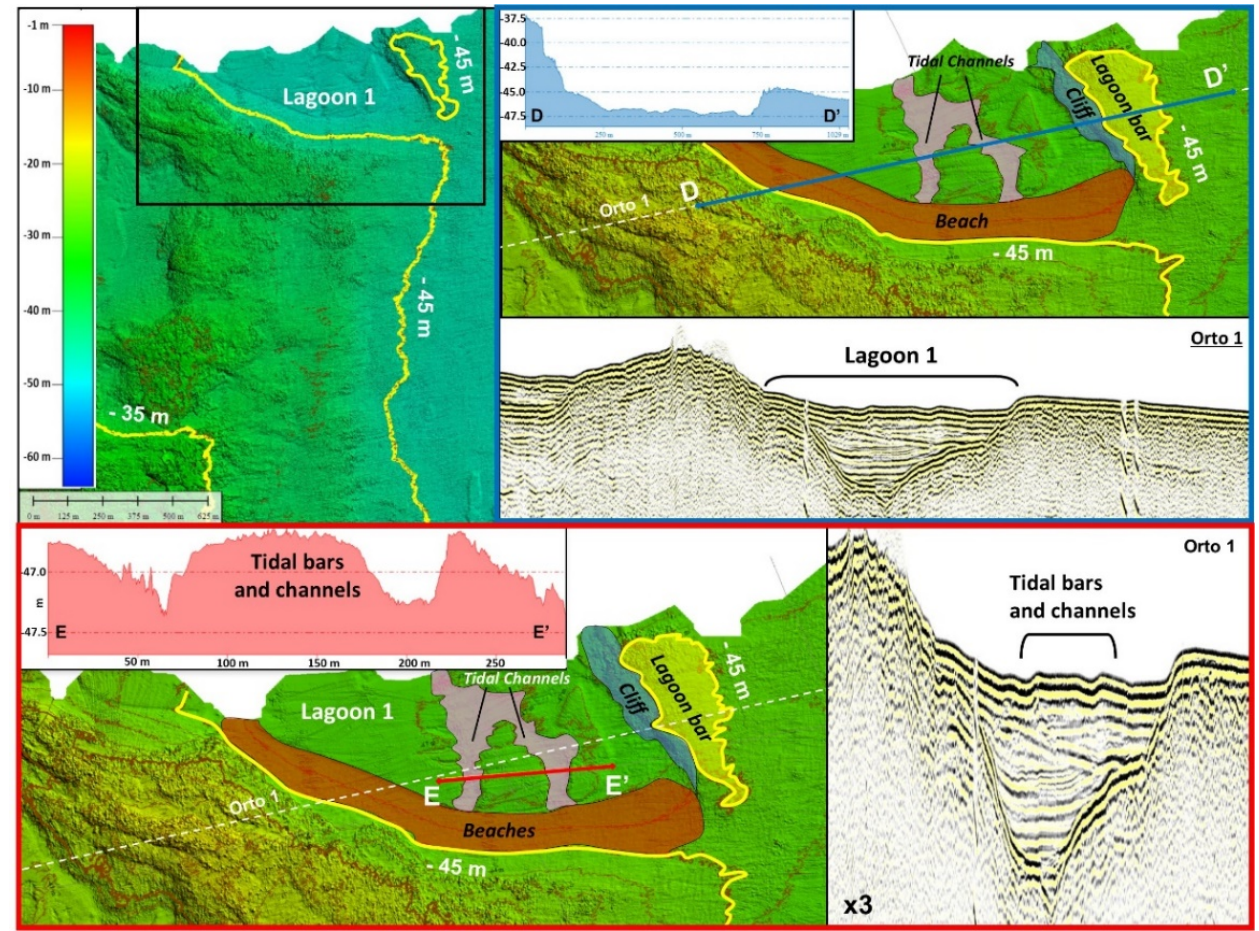

Figure 8. Visualization of Lagoon 1 (L1) with Multibeam data (profile D-D') and its seismicstratigraphic setting (Orto 1). The profile $\mathrm{E}-\mathrm{E}^{\prime}$ represents a detail of the central portion with the development of a system of tidal bars-channels.

Westwards, the $-35 \mathrm{~m}$ contours with irregular trend bounds another depression elongated in the N-S direction with a sub-elliptical shape and a width of $0.8 \mathrm{~km}^{2}$ (Figure 9). This is interpreted as a second lagoon and is named Lagoon 2 (L2). It most probably continues to the north, outside from the available data, and is confined to the east and west by two highs (on average about $5 \mathrm{~m}$ ), interpreted as two paleo-cliffs (Figure 9, profile $\left.\mathrm{F}-\mathrm{F}^{\prime}\right)$. The western cliff shows a locally irregular trend and traces of a cuspate coastline 
southwards. On the contrary, the high eastern cliff has an arched morphology with convexity towards the east and is interpreted as lagoon depositional bars that divided L2 from the open sea (Figure 9).

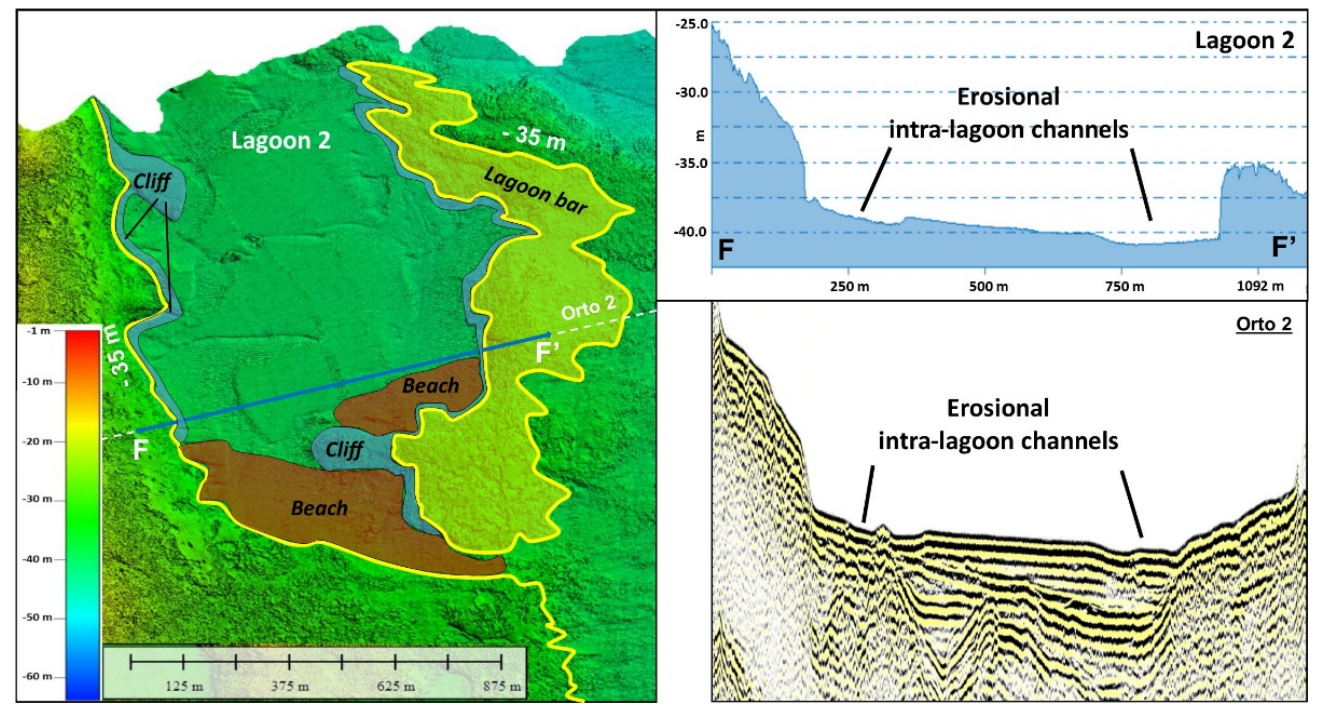

Figure 9. Location of Lagoon 2 (L2) within the northern sector of the study area and the comparison between bathymetric profiles (F-F') and the seismic profile (Orto 2). The central portion of L2 shows the small morphological plateau and the lateral erosional intra-lagoon channels.

Furthermore, Figure 9 shows the seismic-stratigraphic setting (seismic profile of Orto 2), revealing a poor penetration in relation to both cliffs, highlighting that they are probably made up of a hard calcarenite substratum (Figure 4, Figure 10-profile G-G'). On the contrary, along the southwestern edge of L2 (Figure 10, profile $\mathrm{H}-\mathrm{H}^{\prime}$ ), a flat morphology (beach deposits), corresponds with an increase in the penetration of the acoustic signal with reflectors which have good lateral continuity and moderate amplitude.

The flat morphology of the floor of L2 is interrupted by a little depositional plateau, about $2 \mathrm{~m}$ high and $600 \mathrm{~m}$ wide in the east-west direction (Figure 9). The latter is surrounded by two gentle incisions that are interpreted as erosional intra-lagoon channels (Figure 9). Furthermore, the general flat morphology of L2 is locally interrupted in its central portion by shallow, less than one-meter-deep scours (Figures 9 and 10). In this portion of L2, the acoustic character is diffusely homogeneous and likely corresponds to fine-grained sediment (Figure 4), that allows a good imaging of the stratigraphic setting (Figures 9 and 10).

To the south of L2, another narrow opening $(<50 \mathrm{~m})$ highlights the presence of a connection between the paleo-lagoon and the open sea (Figures 9 and 10).

Proceeding towards the coastline, the seabed rises quickly, reaching a depth of $-20 \mathrm{~m}$ in less than $250 \mathrm{~m}$. Here, the irregular acoustic character reveals the presence of a high with a linear north-south trend for about $1.8 \mathrm{~km}$ (Figure 11). It represents the boundary between L2 and another wider depression to the west, interpreted as another lagoon named L3 (Figure 11).

The landward, the western margin of L3 is marked by the $-20 \mathrm{~m}$ contour, which has a N-S irregular trend, highlighting the presence of different types of paleo-coastal forms (Figure 11). Two small re-entrances in the lagoon's landward margin have a flat seafloor and are (about $200 \mathrm{~m}$ wide) interpreted as "pocket paleo-beaches", whereas a marked, narrow, V-shaped incision, running from west to east, is interpreted as the trace of a paleo-river (Figures 11 and 12). The latter is connected with a paleo delta, showing the presence of numerous distributary channels (Figure 12). 


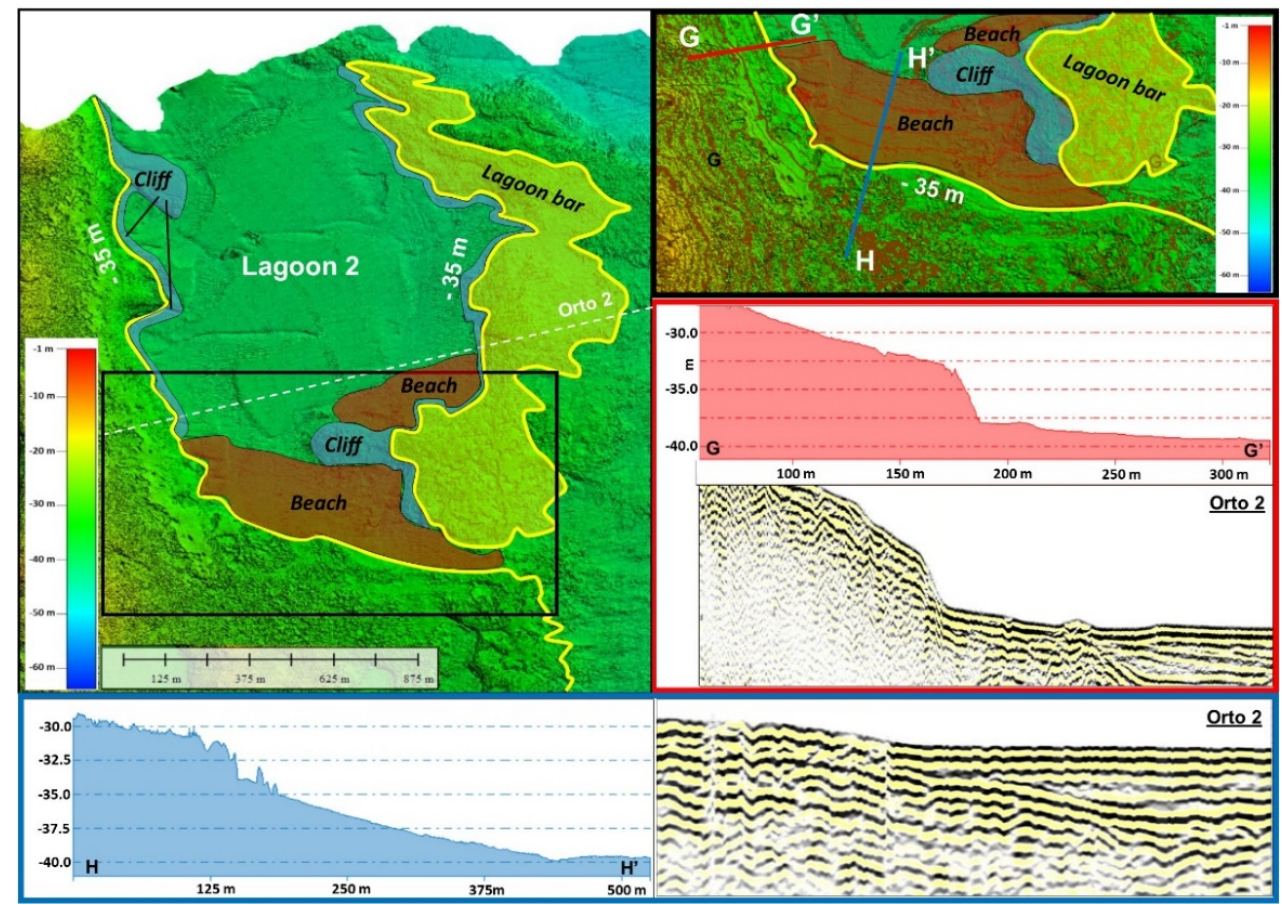

Figure 10. Comparison between the bathymetric profiles $\left(\mathrm{G}-\mathrm{G}^{\prime}\right.$ and $\left.\mathrm{H}-\mathrm{H}^{\prime}\right)$ and the seismic profile (Orto 2) of the morphological boundaries of Lagoon 2 (L2).

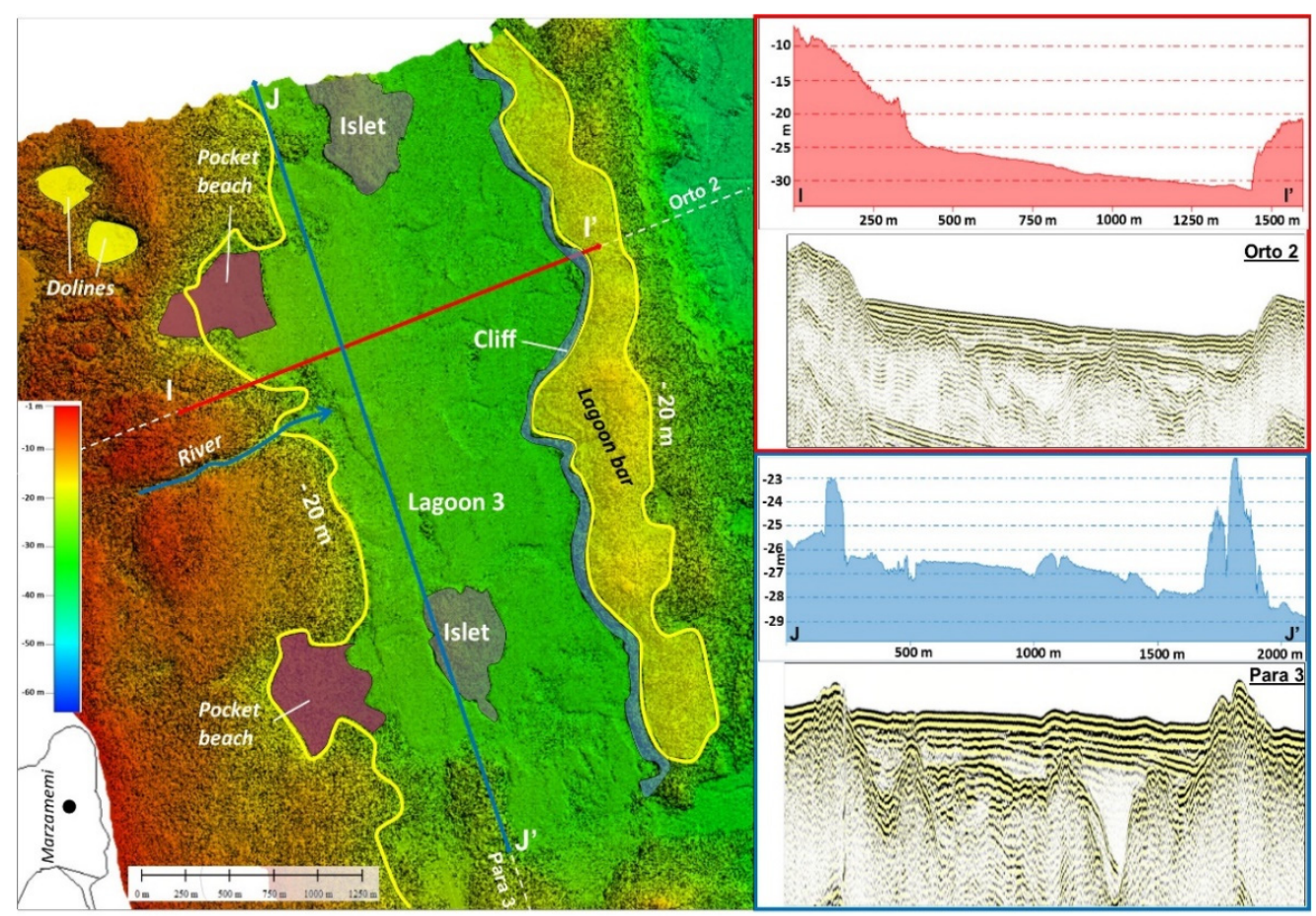

Figure 11. Location of Lagoon 3 (L3) within the Multibeam dataset (profiles $\mathrm{I}-\mathrm{I}^{\prime}$ and $\mathrm{J}-\mathrm{J}^{\prime}$ ) and seismic profiles oriented orthogonally (Orto 2) and longitudinally (Para 3) relative to the current Marzamemi coastline. 


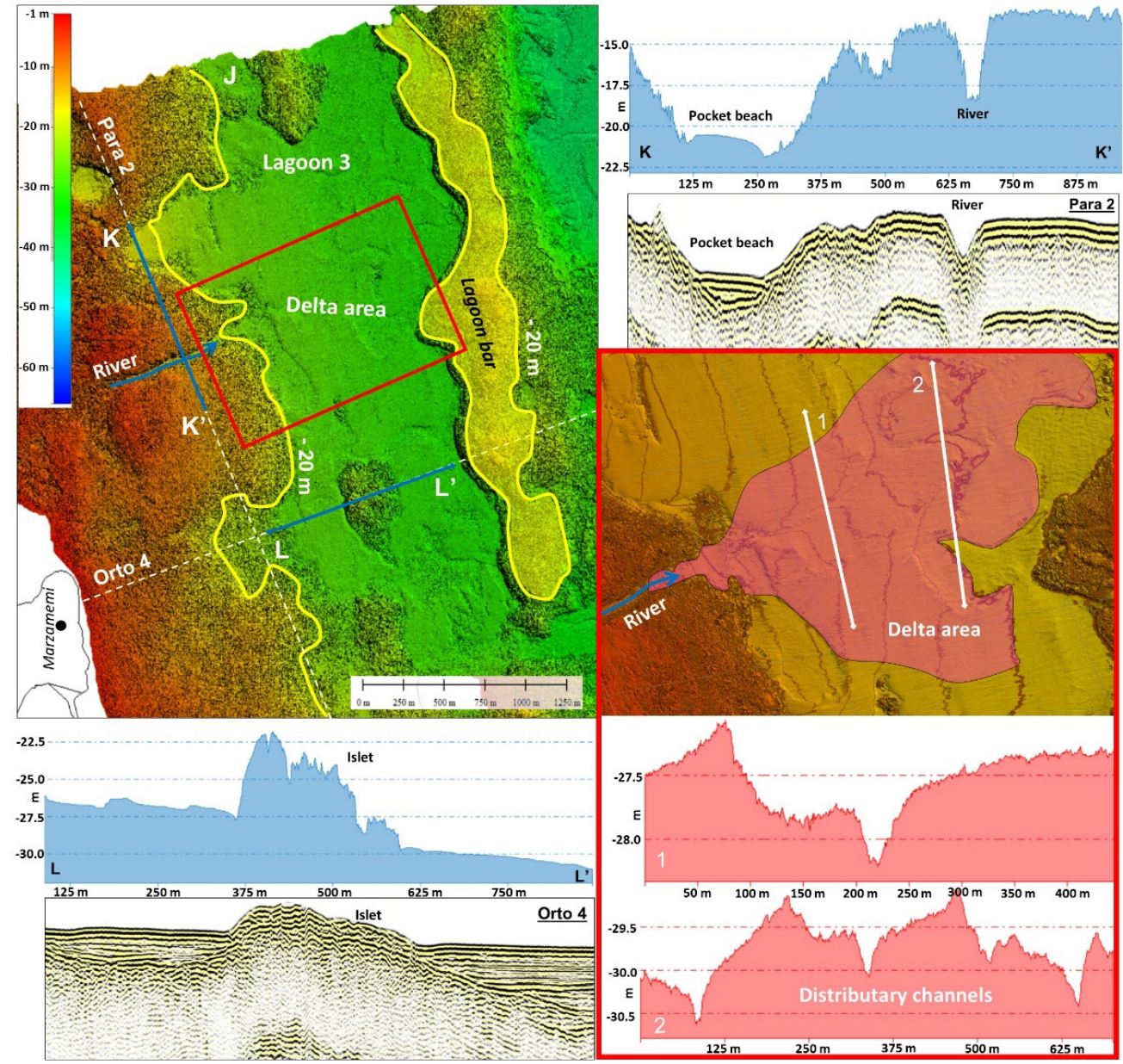

Figure 12. The main morphological features of Lagoon 3 (L3). The $K-K^{\prime}$ profile and the seismic profiles show the morpho-stratigraphic setting of the pocket beaches and of the main incision of this area. The box in red shows the peculiarities of the "delta area" in the central portion of L3. The $\mathrm{L}-\mathrm{L}^{\prime}$ profile and the seismic profile of Orto 4 show the morpho-stratigraphic setting of the islet in the southern portion of L3.

In the southern portion of L3 a morphological high is clearly visible (Figure 12, profile $\mathrm{L}-\mathrm{L}^{\prime}$ ), characterized by an acoustic character markedly more irregular than that of the majority the of sedimentary deposits inside L3. It is interpreted as a paleo-islet, probably the last witness of the substratum in this portion. The seismic profile of Orto 4 confirms its distinctive, inhomogeneous acoustic character especially in its most superficial portion (Figure 12), probably due to the development of a biogenic cover. At the base of the islet, several continuous incisions (about $<1 \mathrm{~m}$ deep) are indicative of active small channels on the seabed where the energy of the currents increases due to the topographic constriction (Figure 12).

Towards the west, landward of L3, the seabed is homogeneous at the large-scale, maintaining an acoustic character due to the outcrop of the substratum on the seabed (Figure 4). This uniformity is interrupted only by the local development of some sub-circular depressions corresponding with karst forms interpreted as dolines (Figure 12). Similar to the other lagoons, L3 shows a narrow opening to the south that represents a discontinuity in the barrier where a connection with the open sea occurred (Figures 11 and 12).

\subsection{Southern Sector}

The southern sector extends for about $12 \mathrm{~km}^{2}$ and is characterized by a minor morphological variability and a small number of types of depositional forms. Nevertheless, two sub-sectors, characterized by some differences in their acoustic features, can be distin- 
guished; they are separated approximately by the $-35 \mathrm{~m}$ contour (Figure 13), as showed by the $\mathrm{M}-\mathrm{M}^{\prime}$ and $\mathrm{N}-\mathrm{N}^{\prime}$ profiles. In the landward area, from the $-5 \mathrm{~m}$ contour to the $-35 \mathrm{~m}$ contour, the seabed is moderately jagged, due to the widespread outcrops of the calcarenite substratum, locally interrupted by the development of some Posidonia Oceanica colonies (Figure 4 ). Conversely, in the seaward sector, from the $-35 \mathrm{~m}$ contour to the $-60 \mathrm{~m}$ contour, the seabed gently deepens towards the east, forming a uniform portion of the continental shelf.

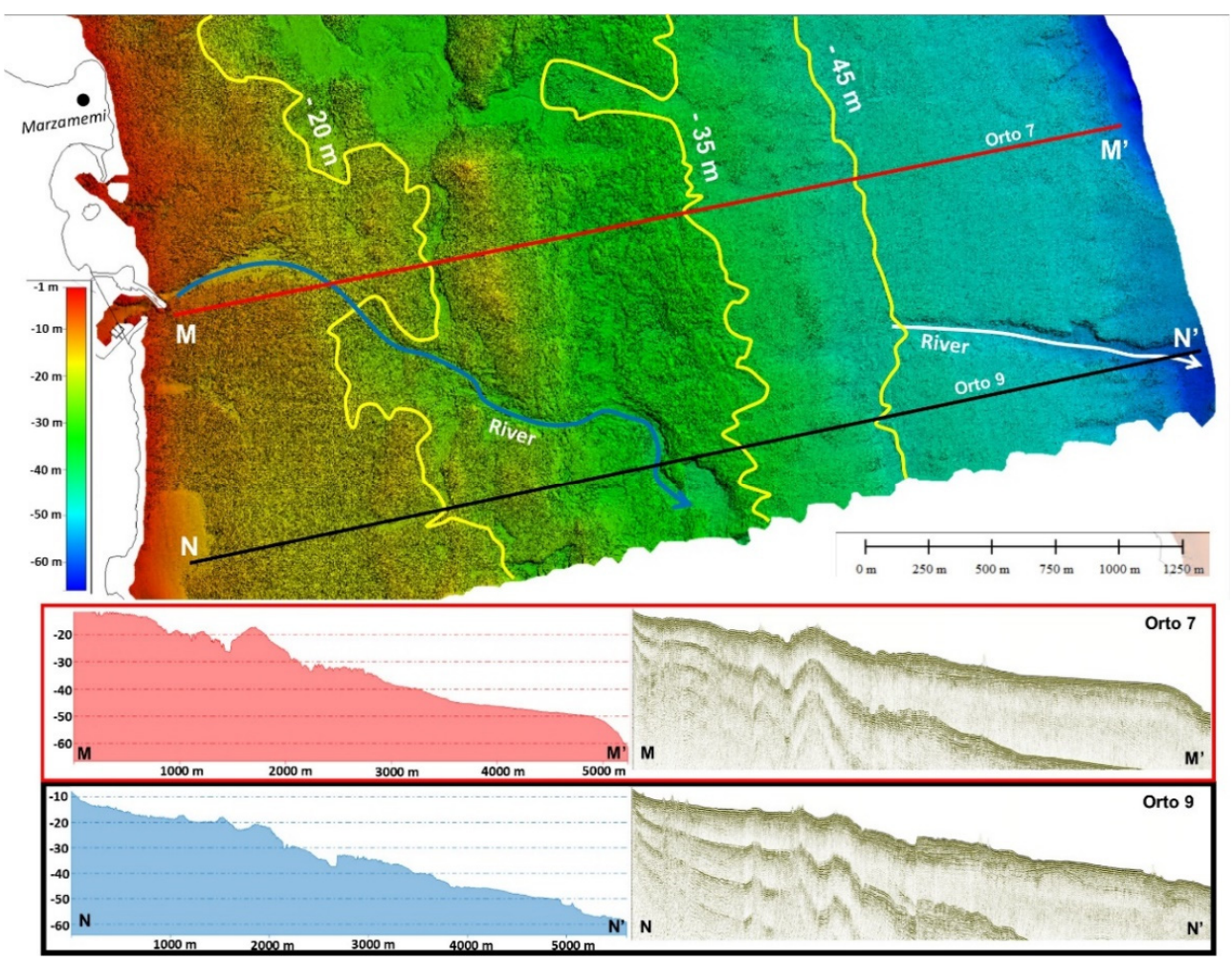

Figure 13. Visualization of the main features of the southern sector of the study area. The M- $\mathrm{M}^{\prime}$ and $\mathrm{N}-\mathrm{N}^{\prime}$ bathymetric profiles and the seismic profiles of Orto 7 and Orto 9 show all the morphostratigraphic settings of this sector.

Inside the proximal portion, a deep incision (on average $>3 \mathrm{~m}$ ) affects the calcarenite seabed (Figure 14). It begins near the Marzamemi harbor and continues southeastwards, showing a series of irregular turns along its eastward path. This incision is interpreted as a paleo-river, whose course likely reflects the morphology inherited from the pre-existing substratum. Furthermore, Figure 14 shows the evolution from west to east of this paleoriver, through the images of four profiles $(1,2,3$, and 4$)$ orthogonal to its direction. Profile 1 shows that landward, the paleo-riverbed is quite regular and sub-horizontal and is flanked by high (about $3 \mathrm{~m}$ ) and regular banks. Profile 2 shows a shallow and more irregular incision. Profile 3 shows a new deepening of the riverbed and the development of two morphologically different riverbanks: low and irregular to the southwest, high and abrupt to the northeast. A similar morphology of the riverbanks is shown in Profile 4 but here the paleo-riverbed is wider, highlighting the distal tendency to branch into sub-incisions.

In the distal portion (from $-35 \mathrm{~m}$ to $-60 \mathrm{~m}$ ), the homogeneous relatively smooth seafloor is interrupted by another incision oriented approximately northwest-southeast. It is interpreted as a paleo-river characterized by a rather linear course and a paleo-riverbed that tends to widen and deepen seaward.

Profiles 1, 2, and 3 in Figure 15 highlight the morphological variations of the paleoriver incision. Profile 1 shows an irregular and shallow riverbed (about $2 \mathrm{~m}$ ) bordered by sub-vertical banks. Profile 2, on the other hand, shows a more regular and deeper riverbed (>3 m), characterized by banks with different inclinations. Finally, Profile 3 highlights the 
widening of the riverbed with a depth of up to about $4 \mathrm{~m}$. The acoustic character (high acoustic penetration, moderate frequency, and good lateral continuity of the reflectors) within this incision can be correlated with a not very compact fine-grained sediment.
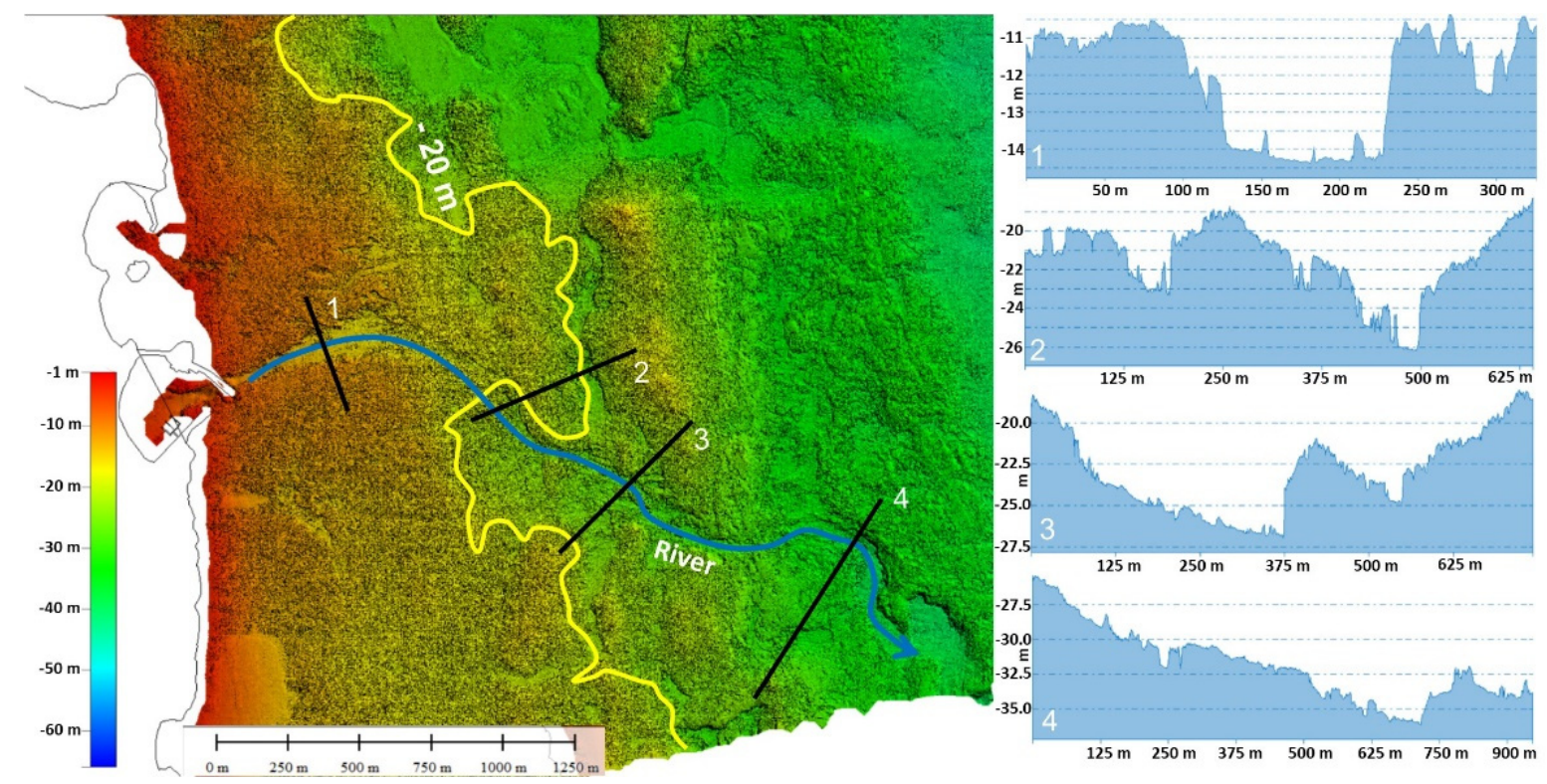

Figure 14. Proximal portion of the southern sector. Profiles 1, 2, 3, and 4 show the morphological variations from northwest to southeast of the main incision described in the area.

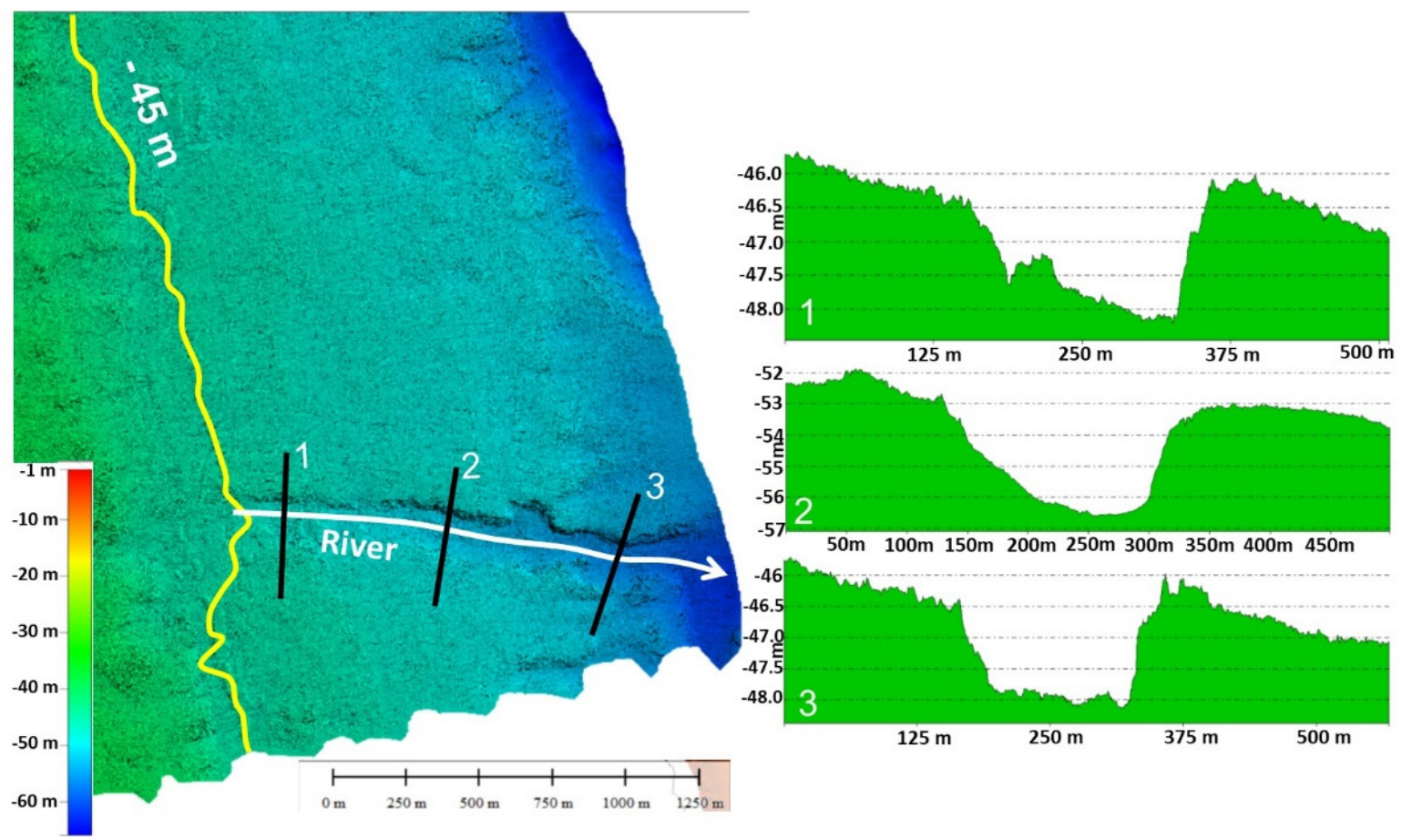

Figure 15. Distal portion of the southern sector. Profiles 1, 2, and 3 show the morphological variations from northwest to southeast of the main incision described in the area.

\section{Discussion}

Following their subaerial exposure, during the last glacial maximum, the late Quaternary sedimentary evolution of the Mediterranean continental shelves is the expression of the last transgressive and highstand system tracts [47]. The offshore sector of the Marza- 
memi village represents an exemplary site for the observation of the succession of diverse sedimentary environments that developed during the progressive submersion of the shelf area during the last sea level rise. In fact, this area not only records the stratigraphic peculiarities of the two system tracts [23], but it also allows a detailed analysis of the geomorphological features that trace the sea level history at the seabed (Figure 16).

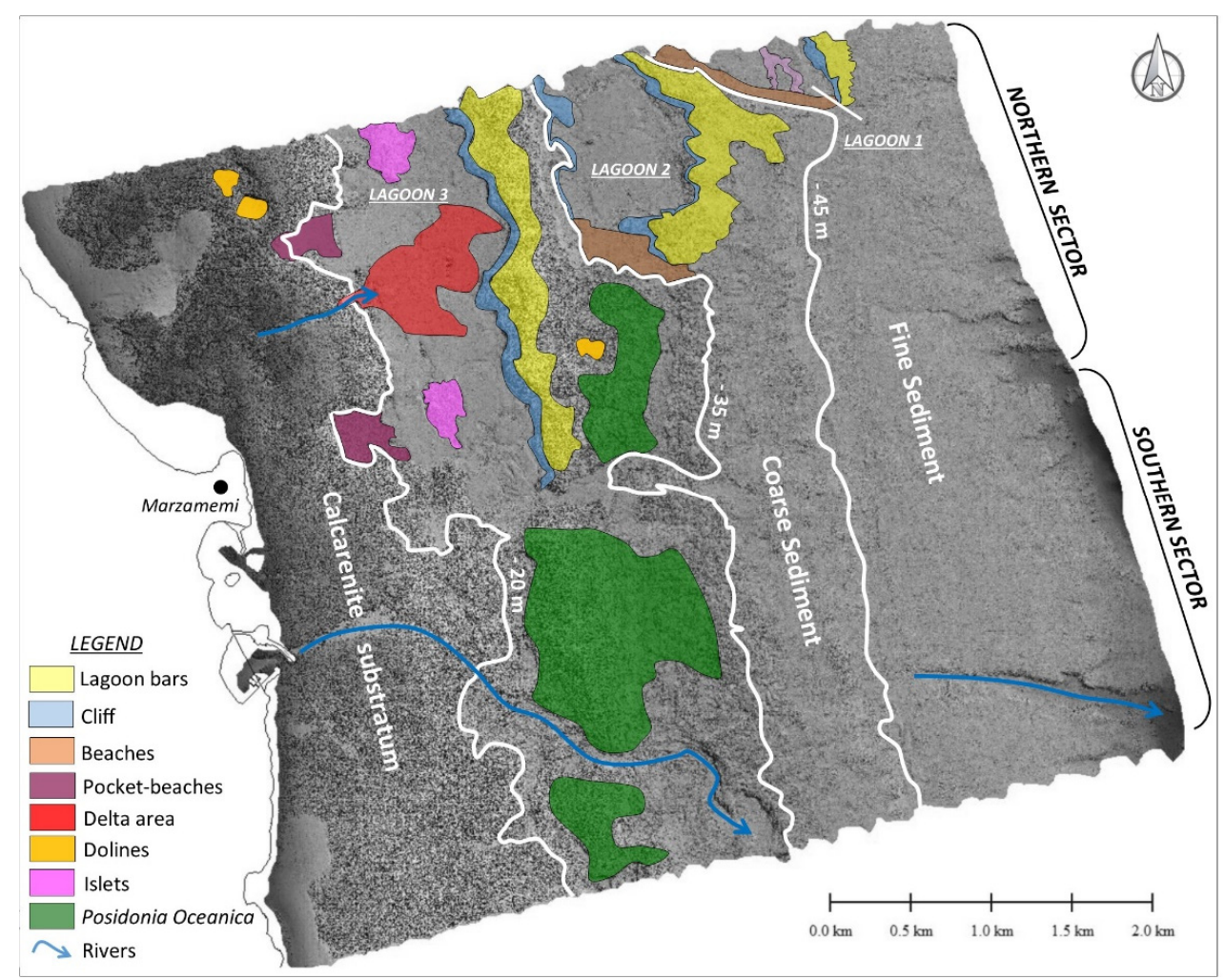

Figure 16. Mapping of the geomorphic elements identified in the proximal offshore area of the Marzamemi village (Syracuse, Sicily) and connected to the Holocene sea-level variations.

In agreement with the analytical approach of numerous studies in the Mediterranean area [47-50] and from other different parts of the world [10,51-55], our geomorphological study took into consideration the evaluation of three main factors: (i) the lithology of the substratum; (ii) the rate of sea level rise; and (iii) the rate of sediment supply.

Through the comparison with Holocene sea level changes in the Mediterranean area [56] and in other areas of the world [57,58], it is evident that the paleo-coastlines at $-45 \mathrm{~m}$ and $-35 \mathrm{~m}$ are linked with a period characterized by a lowered rate of sea level rise. The data are less conclusive on the coastline at -20 , which in some reconstructions corresponds with a period just predating a further lowering of the rate of sea level rise. Therefore, we can conclude that at least two observed coastlines developed during a period of a lowered rate of sea-level rise.

Considering that the history of sea level oscillations must be the same in the whole study area, the geomorphological variability between the northern and southern sectors of the study area must be controlled by the rate of sediment supply and the paleo-topography.

Our data do not allow a quantitative estimate of the rate of sediment supply during the study interval. However, the analysis of the present-day hydrographic network in the hinterland can be used as a proxy for differences in sediment supply in the offshore regions. The northern sector-characterized by the development of various barrier-lagoon systems - correlates with a hydrographic system capable of guaranteeing a substantial sedimentary supply to the north of the Marzamemi village. Conversely, the southern sector of the study area-characterized by a general starved character-can be linked with 
small and undeveloped rivers, capable of delivering scarce quantities of sediment to the offshore regions.

\subsection{Northern Sector: Barrier-Lagoon Systems}

The northern sector is characterized by the development of three barrier-lagoon systems (L1, L2, and L3; Figure 16), whose position marks the main steps of last sea level rise. These lagoons show at least three common morphological features: (1) a predominant development of cliffs along their eastern margins and of beaches along their western margins, probably due to the differential circulation of deep paleo-currents; (2) a seafloor with a widespread homogeneous acoustic character correlated to the presence of fine-grained sediments; (3) a narrow paleo-connection with the open sea in their southern portions.

The three barrier-lagoon systems are separated by two ridges showing different morphological features, probably due to different genetic mechanisms. In particular, the boundary between L1 and L2 is represented by a small cuspate ridge, whose genesis is probably strictly connected to the depositional evolution of the typical barrier-lagoon system. Conversely, the boundary between L2 and L3 is more jagged and elongated in a north-south direction, crossing a large part of the study area and marking the pre-existing morphology of the old substratum. These differences can be ascribed to the exclusively depositional character of the ridge, the limit seaward of L2. A barrier island, controlled solely by the pattern of the oceanographic processes, represents the lagoon's seaward boundary. On the contrary, a structural high was the first order control on the seaward limit of L3, determining the location and the successive development of a depositional barrier island.

Furthermore, the development of the barrier-lagoon systems in the northern sector correlates with the onshore geomorphological setting in a rather large area, a few kilometers to the north of the Marzamemi village. Here, a sizeable hydrographic basin, known as the Vendicari Reserve, is bounded seaward by a sandy dune-beach system. The coastal lacustrine-palustrine system (called "Pantani di Vendicari") consists of three flooded coastal lakes and is flanked on land by widespread karst forms [18]. The evolution of the Vendicari coastal plain is connected to the development of lake-karst systems in relation to late Quaternary sea level changes [18].

\subsection{Southern Sector: Starved Area}

In general, the southern sector of the study area shows minor geomorphological variability in comparison with the northern sector (Figure 16). As mentioned, we interpret this as being due to an underdeveloped hydrographic network in the adjacent onshore, resulting in a low sediment supply rate during the Quaternary. As a consequence, the calcarenite substratum outcrops extensively in the southern sector. Here, in addition, the vast outcrop of calcarenites at the seabed furnished a hard substratum for the development of Posidonia Oceanica meadows. The distribution of these meadows occurs in both sectors of the study area, but with a greater concentration in the southern sector, where the calcarenite substratum - the preferential habitat for the development of Posidonia Oceanica—outcrops more extensively. Therefore, we affirm that the different depositional setting between the northern and southern sector also controls the spread of organisms.

The flat seafloor of the southern area is interrupted by two relatively deep, narrow incisions, one located in the proximal portion and one in the distal portion of the Marzamemi coastline. They are interpreted as paleo-rivers and affect the calcarenite seabed whose paleo-topography determines their trajectory and areal development. In the southern sector the development of these paleo-rivers is particularly marked because the poor sediment supply rate probably did not hide their morphology. Conversely, in the northern sector, the considerable sedimentary input has buried most of the paleo-rivers, as confirmed by the available seismic profiles. 


\subsection{Karst and Present Day Geomorphological Features}

Numerous karst forms have also been recognized in the offshore area of Marzamemi, very similar to those outcropping along the actual coastline and in the Vendicari Reserve. For this reason, we affirm that similar karst processes up to the coastal plain of Marzamemi must have been extended, involving the depositional evolution of the transgressive system track and the calcarenite substratum. In fact, the latter is affected by numerous karst forms (poljies and dolines; Figure 16), similar to those outcropping onshore of this portion of southeastern Sicily [37] and in other areas of the Mediterranean Sea [54,55].

Finally, the bathymetric analysis allowed the identification of at least two morphological features at the small scale (below one meter) that highlight the present-day activity of currents in the study area: (i) the widespread presence of shallow incisions at the basis of cliffs and intra-lagoon islets; (ii) the development of bedforms (such as ripples) within the paleo-rivers and, locally, where the medium-fine-grained sediments dominate. We suggest that the location of these features is controlled mainly by the distribution of the paleo-topography and the transgressive bodies.

\section{Conclusions}

1. Through the integrated interpretation of bathymetric (Multibeam data) and seismicstratigraphic data (Sparker seismic profiles), we have provided a reconstruction of the depositional history of the offshore sector of the Marzamemi village, during the last sea-level rise. The main result of our analysis is that the rate of sediment supplyconnected with the differential development of the hydrographic networks in the northern and southern area-and the paleo-topography control the geomorphological variability of transgressive depositional environments between the northern and southern sectors;

2. The northern sector is characterized by the development of three barrier-lagoon systems whose position marks the main steps of the last sea level rise. The lagoons are bounded seaward by two ridges with different genetic meanings: the first, seawards, is exclusively associated with the depositional evolution of a typical barrier system; the second, landwards, represents a structural high connected mainly to the paleotopography of the area.

3. The southern sector is characterized by the incisions corresponding to paleo-rivers, whose path is strongly conditioned by the paleo-topography inheritance.

4. In the southern sector, the relatively scarce sediment supply rate did not heal the morphology of the paleo-rivers. Conversely, in the northern sector, the considerable sediment supply rate has buried most of the paleo-rivers, as confirmed by the available seismic profiles.

5. Karst processes have a significant impact on the development of transgressive bodies and on the features of the calcarenite seabed, similar to those observed in the onshore portions of the Marzamemi hinterland (Vendicari Reserve).

6. The different depositional setting between the northern and southern sectors also controls the distribution of organisms, with a greater concentration of Posidonia Oceanica meadows in the southern sector, where the rocky substrate outcrops more extensively.

7. The shallow incisions within the barrier-lagoon systems and the development of bedforms, reveal the present-day deep current activity whose circulation depends on the distribution of the transgressive bodies.

Author Contributions: Conceptualization, S.D. and F.G.; methodology, S.D.; software, S.D.; validation, F.G. and A.D.S.; formal analysis, F.G.; investigation, A.D.S.; resources, S.D. and A.D.S.; data curation, S.D. and F.G.; writing —original draft preparation, S.D., F.G. and A.D.S.; writing-review and editing, S.D., F.G., A.D.S. and L.B.; visualization, S.D., F.G., A.D.S. and L.B.; supervision, F.G and A.D.S.; project administration, A.D.S.; funding acquisition, A.D.S. All authors have read and agreed to the published version of the manuscript. 
Funding: The study has been performed within the framework of the Project $n$. 183371-CUP E66C18001300007 "Attraction and International Mobility" (AIM) funded by the Italian MIUR (Ministry of Instruction and University and Research) (D.D. 407/27.2.2018) Action 1.2 Axis I-PONR\&I 2014-2020 Blue Growth Area (Beneficiary: Salvatore Distefano; Scientific Responsible: Agata Di Stefano). Grants also come from the project "PIACERI 2020-22 linea 2-DATASET" (Scientific Responsible: Rosanna Maniscalco).

Data Availability Statement: Not applicable.

Acknowledgments: The authors wish to thank the Editors, Luigi Bruno and Bruno Campo, as well as two anonymous reviewers, for their constructive comments that helped to significantly improve the manuscript, and Ashley Zhang, from the Geosciences MDPI Branch Office, for her assistance and support. Alfonso Analfino and Giuseppe Catalano are warmly thanked for their contribution during the fieldwork and for the acquisition of the Multibeam data and seismic profiles.

Conflicts of Interest: The authors declare no conflict of interest.

\section{References}

1. Storms, J.E.A.; Weltje, G.J.; Terra, G.J.; Cattaneo, A.; Trincardi, F. Coastal dynamics under conditions of rapid sea-level rise: Late Pleistocene to Early Holocene evolution of barrier-lagoon systems on the northern Adriatic shelf (Italy). Quat. Sci. Rev. 2008, 27, 1107-1123. [CrossRef]

2. Swift, D.J.P. Coastal erosion and transgressive stratigraphy. J. Geol. 1968, 76, 444-456. [CrossRef]

3. Belknap, D.F.; Kraft, J.C. Preservation potential of transgressive coastal lithosomes on the U.S. Atlantic shelf. Mar. Geol. 1981, 32, 429-442. [CrossRef]

4. Nummedal, D.; Swift, D.J.P. Transgressive stratigraphy at sequence-bounding unconformities: Some principles derived from Holocene and Cretaceous examples. In Sea Level Fluctuation and Coastal Evolution; Nummedal, D., Pilkey, O.H., Howard, J.D., Eds.; Special Publication; SEPM: Tulsa, OK, USA, 1987; pp. 241-260.

5. Swift, D.J.P.; Phillips, S.; Thorne, J.A. Sedimentation on Continental Margins, IV: Lithofacies and depositional systems. In Shelf Sand and Sand-Stone Bodies: Geometry, Facies, and Sequence Stratigraphy; Swift, D.J.P., Ed.; Special Publication, International Association for Sediment; Wiley \& Sons: Hoboken, NJ, USA, 1991; Volume 14, pp. 89-152.

6. Cattaneo, A.; Steel, R.J. Transgressive deposits: A review of their variability. Earth Sci. Rev. 2003, 62, 187-228. [CrossRef]

7. Zhang, W. Barrier Island. In Encyclopedia of Estuaries. Encyclopedia of Earth Sciences Series; Kennish, M.J., Ed.; Springer: Dordrecht, The Netherlands, 2015.

8. Kjerfve, B. Coastal lagoons. In Elsevier Oceanography Series; Kjerfve, B., Ed.; Elsevier: Amsterdam, The Netherlands, 1994; Volume 60, pp. 1-8.

9. Boyd, R.; Dalrymple, R.; Zaitlin, B.A. Classification of clastic coastal depositional environments. Sediment. Geol. 1992, 80, 139-150. [CrossRef]

10. Moore, L.J.; List, J.H.; Williams, S.J.; Stolper, D. Complexities in barrier island response to sea level rise: Insights from numerical model experiments, North Carolina Outer Banks. J. Geoph. Res. Earth Surf. 2010, 115, F03004. [CrossRef]

11. Ruggieri, R.; De Waele, J. Lower-to Middle Pleistocene flank margin caves at Custonaci (Trapani, NW Sicily) and their relation with past sea levels. Acta Carsologica 2014, 43, 11-22. [CrossRef]

12. Canora, F.; Fidelibus, D.; Spilotro, G. Coastal and inland karst morphologies driven by sea level stands: A GIS based method for their evaluation. Earth Surf. Process. Landf. 2012, 37, 1376-1386. [CrossRef]

13. Sweeting, M.M. Karst Landforms; Columbia University Press: New York, NY, USA, 1978; p. 362.

14. Jennings, J.N. Karst Geomorphology, 2nd ed.; Blackwell: New York, NY, USA, 1985; p. 293.

15. James, N.P.; Choquette, P.W. Paleokarst; Springer Science and Business Media: New York, NY, USA, 1988 ; p. 416.

16. Palmer, A.N. Groundwater processes in karst terranes. In Groundwater Geomorphology: The Role of Subsurface Water in Earth Surface Processes and Landforms; Higgins, C.G., Coates, D.R., Eds.; Spec. Paper 252; The Geological Society of America, Inc.: Boulder, CO, USA, 1990; pp. 177-209.

17. Ford, D.C.; Williams, P. Karst Hydrogeology and Geomorphology; Wiley \& Sons: Hoboken, NJ, USA, 2007 ; p. 562.

18. Gracia, F.J.; Geremia, F.; Privitera, S.; Amore, C. The probable karst origin and evolution of the Vendicari coastal lake system (SE Sicily, Italy)/Verjetni Kraski Izvor In Razvoj Obalnega Jeserskega Sistema Vendicari (Jv Sicilija, Italija). Acta Carsologica 2014, 43, 215.

19. Gams, I. The polje: The problem of its definition. Z. Geomorph. 1978, 22, 170-181.

20. Julian, M.; Nicod, J. Les karsts des Alpes du Sud et de Provence. Z. Geomorph. 1989, 75, 1-48.

21. Gracia, F.J.; Gutiérrez, F.; Gutiérrez, M. The Jiloca karst polje-tectonic graben (Iberian Range, NE Spain). Geomorphology 2003, 52, 215-231. [CrossRef]

22. Di Maggio, C.; Madonia, G.; Parise, M.; Vattano, M. Karst of Sicily and its conservation. J. Cave Karst Stud. 2012, 74, 157-172. [CrossRef] 
23. Distefano, S.; Gamberi, F.; Baldassini, N.; Di Stefano, A. Quaternary Evolution of Coastal Plain in Response to Sea-Level Changes: Example from South-East Sicily (Southern Italy). Water 2021, 13, 1524. [CrossRef]

24. Burollet, P.F.; Mugniot, G.M.; Sweeney, P. The geology of the Pelagian Block: The margins and basins of Southern Tunisia and Tripolitania. In The Ocean Basins and Margins; Nairn, A., Kanes, W., Stelhi, F.G., Eds.; Plenum Press: New York, NY, USA, 1978; pp. 331-339.

25. Lentini, F.; Carbone, S.; Catalano, S. Main structural domains of the central mediterranean region and their Neogene tectonic evolution. Boll. Geofis. Teor. Appl. 1994, 36, 141-144.

26. Catalano, S.; Romagnoli, G.; Tortorici, G. Kinematics and dynamics of the Late Quaternary rift-flank deformation in the Hyblean Plateau (SE Sicily). Tectonophysics 2010, 486, 1-14. [CrossRef]

27. Lentini, F.; Carbone, S. Geologia della Sicilia-Geology of Sicily. Mem. Descr. Carta Geol. Ital. 2014, 95, 31-98.

28. Argnani, A.J. The Gela nappe: Evidence of accretionary mélange in the Maghrebian foredeep of Sicily. Mem. Soc. Geol. Ital. 1989, $38,419-428$.

29. Bianchi, F.; Carbone, S.; Grasso, M.; Invernizzi, G.; Lentini, F.; Longaretti, G.; Merlini, S.; Mostardini, F. Sicilia orientale: Profilo geologico Nebrodi-Iblei. Mem. Soc. Geol. Ital. 1989, 38, 429-458.

30. Finetti, I.R.; Lentini, F.; Carbone, S.; Del Ben, A.; Di Stefano, A.; Guarnieri, P.; Pipan, M.; Prizzon, A. Crustal tectonostratigraphy and geodynamics of the Southern Apennines from CROP and other integrating seismic and geological data. In CROP Project: Deep Seismic Exploration of the Central Mediterranean and Italy; Finetti, I.R., Ed.; Elsevier: Amsterdam, The Netherlands, 2005; pp. 225-261.

31. Distefano, S.; Gamberi, F.; Di Stefano, A. Stratigraphic and structural reconstruction of an offshore sector of the Hyblean Foreland ramp (southern Italy). Ital. J. Geosci. 2019, 138, 390-403. [CrossRef]

32. Ghisetti, F.; Vezzani, L. The structural features of the Hyblean Plateau and the Mount Judica area (South-Eastern Sicily): A microtectonic contribution to the deformational history of the Calabrian Arc. Boll. Soc. Geol. Ital. 1980, 99, 55-102.

33. Grasso, M.; Lentini, F. Sedimentary and tectonic evolution of the eastern Hyblean Plateau (Southeast Sicily) during Late Cretaceous to Quaternary time. Paleogeogr. Paleoclimatol. Palaeoecol. 1982, 39, 261-280. [CrossRef]

34. Pedley, H.M.; Cugno, G.; Grasso, M. Gravity slide and resedimentation processes in a Miocene carbonate ramp, Hyblean Plateau, southeastern Sicily. Sediment. Geol. 1992, 79, 189-202. [CrossRef]

35. Romagnoli, G.; Catalano, S.; Pavano, F.; Tortorici, G. Geological map of the Tellaro River Valley (Hyblean Foreland, southeastern Sicily, Italy). J. Maps 2015, 11, 66-74. [CrossRef]

36. Carveni, P.; Romano, R.; Capodicasa, A.; Tricomi, S. Geologia dell'area vulcanica di Capo Passero (Sicilia sud-orientale). Mem. Soc. Geol. Ital. 1991, 47, 431-447.

37. Groppelli, G.; Pasquarè, F.A. Nuovi contributi alla ricostruzione della stratigrafia vulcanica dell'area di Capo Passero, Siciliasudorientale, nel quadro del vulcanismo del Cretacico superiore nel Plateau Ibleo. Boll. Soc. Geol. Ital. 2004, 123, $275-290$.

38. La Rosa, N. Note esplicative della carta Geologica d'Italia. Foglio 652 “Capo Passero” alla scala 1:50,000. Serv. Geol. Ital. 1974, $16,1-17$.

39. Colacicchi, R. Geologia del territorio di Pachino. Geol. Roman. 1963, 2, 343-404.

40. Carbone, S.; Lentini, F.; Pistorio, A. Il geosito "Calcari a rudiste e coralli del Cretacico superiore di Capo Passero-Pachino" (Monti Iblei, Sicilia SE). Geol. Ambiente 2016, 3, 14-19.

41. Gennari, R.; Iaccarino, S.M.; Di Stefano, A.; Sturiale, G.; Cipollari, P.; Manzi, V.; Roveri, M.; Cosentino, D. The Messinian- Zanclean boundary in the Northern Apennine. Stratigraphy 2008, 5, 309-325.

42. De Visser, J.P.; Ebbing, J.H.J.; Gudjonsson, L.; Hilgen, F.J.; Jorissen, F.J.; Verhallen, P.J.J.M.; Zevenboom, D. The origin of rhythmic bedding in the Pliocene Trubi Formation of Sicily, southern Italy. Palaeogeogr. Palaeoclimatol. Palaeoecol. 1989, 69, 45-66. [CrossRef]

43. Riforgiato, F.; Foresi, L.M.; Di Stefano, A.; Aldinucci, M.; Pelosi, N.; Mazzei, R.; Salvatorini, G.; Sandrelli, F. The Miocene/Pliocene boundary in the Mediterranean area: New insights from a high-resolution micropaleontological and cyclostratigraphic study (Cava Serredi section, Central Italy). Palaeogeogr. Palaeoclimatol. Palaeoecol. 2011, 305, 310-328. [CrossRef]

44. Taviani, M.; Angeletti, L.; Campiani, E.; Ceregato, A.; Foglini, F.; Maselli, V.; Trincardi, F. Drowned karst landscape offshore the Apulian margin (southern Adriatic Sea, Italy). J. Cave Karst Stud. 2012, 74, 197-212. [CrossRef]

45. Distefano, S.; Gamberi, F.; Baldassini, N.; Di Stefano, A. Neogene stratigraphic evolution of a tectonically controlled continental shelf: The example of the Lampedusa Island. Ital. J. Geosci. 2019, 138, 418-431. [CrossRef]

46. Rende, S.F.; Bosman, A.; Di Mento, R.; Bruno, F.; Lagudi, A.; Irving, A.D.; Cellini, E. Ultra-High-Resolution Mapping of Posidonia oceanica (L.) Delile Meadows through Acoustic, Optical Data and Object-based Image Classification. J. Mar. Sci. Eng. $2020,8,647$. [CrossRef]

47. Ercilla, G.; Díaz, J.I.; Alonso, B.; Farran, M. Late Pleistocene-Holocene sedimentary evolution of the northern Catalonia continental shelf (northwestern Mediterranean Sea). Cont. Shelf Res. 1995, 15, 1435-1451. [CrossRef]

48. Ercilla, G.; Alonso, B.; Baraza, J. Sedimentary evolution of the northwestern Alboran Sea during the Quaternary. Geo-Mar. Lett. 1992, 12, 144-149. [CrossRef]

49. Farràn, M.; Maldonado, A. The Ebro continental shelf: Quaternary seismic stratigraphy and growth patterns. Mar. Geol. 1990, 95, 333-352. [CrossRef]

50. Borzì, L.; Anfuso, G.; Manno, G.; Distefano, S.; Urso, S.; Chiarella, D.; Di Stefano, A. Shoreline evolution and environmental changes at the NW area of the Gulf of Gela (Sicily, Italy). Land 2021, 10, 1034. [CrossRef] 
51. Everts, C.H. Sea level rise effects on shoreline position. J. Waterw. Port Coast. Ocean Eng. 1985, 111, 985-999. [CrossRef]

52. FitzGerald, D.M.; Fenster, M.S.; Britt, A.A.; Buynevich, I.V. Coastal impacts due to sea-level rise. Annu. Rev. Earth Planet. Sci. 2008, 36, 601-647. [CrossRef]

53. List, J.H.; Sallenger, A.H.; Hansen, M.E.; Jaffe, B.E. Accelerated relative sea-level rise and rapid coastal erosion: Testing a causal relationship for the Louisiana barrier islands. Mar. Geol. 1997, 140, 347-365. [CrossRef]

54. Parise, M. Geomorphology of the Canale di Pirro karst polje (Apulia, southern Italy). Z. Geomorph. Suppl. 2006, 147, 143.

55. Gracia, F.J.; Gutiérrez, F.; Gutiérrez, M. Origin and evolution of Gallocanta polje. Z. Geomorph. 2002, 46, 245-262. [CrossRef]

56. Bianchi, C.N.; Morri, C.; Chiantore, M.; Montefalcone, M.; Parravicini, V.; Rovere, A. Mediterranean Sea biodiversity between the legacy from the past and a future of change. In Life in the Mediterranean Sea: A Look at Habitat Changes; Nova Science Publishers, Inc.: New York, NY, USA, 2012; Chapter 1; pp. 1-55.

57. Liu, J.P.; Milliman, J.D.; Gao, S.; Cheng, P. Holocene development of the Yellow River's subaqueous delta, North Yellow Sea. Mar. Geol. 2004, 209, 45-67. [CrossRef]

58. Doyle, T.W.; Chivoiu, B.; Enwright, N.M. Sea-Level Rise Modeling Handbook: Resource Guide for Coastal Land Managers, Engineers, and Scientists; US Department of the Interior, US Geological Survey: Lafayette, LA, USA, 2015. 